\title{
PEMANFAATAN PEKARANGAN KELUARGA PETANI DI DESA PARA-LELE, KECAMATAN TATOARENG, KABUPATEN KEPULAUAN SANGIHE
}

\author{
Husni Lais \\ Paulus A. Pangemanan \\ Sherly G. Jocom
}

\begin{abstract}
This study aims to identify the area of yard farmland owned by the farmers' families in the cultivation of vegetables and spices and to identify the amount of costs incurred by the family of farmers for the consumption of vegetables and spices in one month. This study was conducted for three months from the time of preparation to the preparation of the final research report. Activities begin from September to November 2017.The data used are primary data and secondary data. Primary data obtained from the respondents through surveys, documentation, interviews using a list of questions that have been prepared first.Teknik sample used is purposive sampling technique with the number of samples of 30 respondents. With the provisions of the families of farmers who grow vegetables and spices as many as 15 respondent and farm families who do not grow vegetables and spices as many as 15 respondent. Then the data collected will be analyzed descriptively and presented in written form and table. Based on data analysis that has been collected, it is concluded that the area of yard area owned by family of farmers who grow vegetables and spices mostly located in the area between $100 \mathrm{~m}^{2}-120 \mathrm{~m}^{2}$ whereas family of farmers who do not plant vegetables and spices mostly located in the area between $121 \mathrm{~m}^{2}-140$ $\mathrm{m}^{2}$. As for the cost of consumption of vegetables, both farming families who do not plant, the average cost of $R p$ 330,000- Rp 599,000. for the cost of spice consumption of both planting and non-planting farm families, the average cost of Rp 289,000 - Rp.576,000.
\end{abstract}

Keywords: the utilisation of yard area, family farmers, Para-Lele Village, District Tatoareng, Sangihe Islands District

\begin{abstract}
ABSTRAK
Penelitian ini bertujuan untuk mengindentifikasi luas lahan pekarangan yang dimiliki oleh keluarga petani dalam budidaya sayuran-sayuran dan rempah-rempah serta untuk mengindentifikasi besarnya biaya yang dikeluarkan oleh keluarga petani untuk konsumsi sayur-sayuran dan rempah dalam satu bulan. Penelitian ini dilaksanakan selama tiga bulan sejak persiapan hingga penyusunan laporan akhir penelitian.kegiatan dimulai bulan September sampai November 2017. Data yang digunakan adalah data primer dan data sekunder. Data primer diperoleh dari responden melalui survey, dokumentasi, wawancara dengan menggunakan daftar pertanyaan yang sudah disiapkan terlebih dahulu.Teknik sampel yang digunakan adalah teknik purposive sampling dengan jumlah sampel sebanyak 30 responden. Dengan ketentuan keluarga petani yang menanam sayuran dan rempah sebanyak 15 responden dan keluarga petani yang tidak menanam sayuran dan rempah sebanyak 15 responden. Kemudian data yang dikumpulkan akan dianalisis secara deskriptif dan disajikan dalam bentuk tulisan dan tabel. Berdasarkan analisis data yang telah dikumpulkan,diperoleh kesimpulkan bahwa luas lahan pekarangan yang dimiliki oleh keluarga petani yang menanam sayuran dan rempah sebagian besar berada pada luasan antara $100 \mathrm{~m}^{2}$ - $120 \mathrm{~m}^{2}$ sedangkan keluarga petani yang tidak menanam sayuran dan rempah sebagian besar berada pada luasan antara $121 \mathrm{~m}^{2}-140 \mathrm{~m}^{2}$. Sedangkan untuk biaya konsumsi sayur-sayuran baik keluarga petani yang menanam maupun yang tidak menanam , biaya yang dikeluarkan rata-rata Rp 330.000- Rp 599.000. untuk biaya konsumsi rempah-rempah baik keluarga petani yang menanam maupun yang tidak menanam,biaya yang dikeluarkan rata-rata Rp 289.000 - Rp.576.000.
\end{abstract}

Kata kunci: pemanfaatan lahan pekarangan, keluarga petani, Desa Para-Lele, Kecamatan Tatoareng, Kabupaten Kepulauan Sangihe 


\section{PENDAHULUAN}

\section{Latar Belakang}

Indonesia dikenal sebagai negara agraris yang kaya dengan ketersediaan pangan dan rempah yang beranekaragam. Pangan merupakan kebutuhan pokok manusia selain sandang dan papan. Ketersediaan pangan yang cukup menjadi isu nasional untuk menentaskan kerawanan pangan diberbagai daerah. Penyelenggaraan pangan Indonesia diatur dalam Undang - Undang No.18 tahun 2012 yang menekankan adanya pemenuhan pangan di tingkat individu dengan memanfaatkan sumber daya alam, manusia, sosial, ekonomi, kearifan lokal sehingga tercapai ketahanan pangan dan kemandirian pangan.

Pemenuhan pangan pada tingkat individu diselenggarakan melalui kegiatan optimalisasi pemanfaatan lahan pekarangan, kegiatan ini mengantisipasi kerawanan pangan di berbagai daerah. Saleim (2011), menyatakan kerawanan pangan adalah kondisi tidak tercapainya ketahanan pangan ditingkat wilayah maupun rumah tangga/individu. Selain potensi terjadinya kerawanan pangan, permasalahan lain adalah tingkat konsumsi dimana sebagian penduduk Indonesia masih di bawah anjuran pemenuhan gizi. Lahan pertanian yang diusahakan pun sangat bergantung pada musim dan daya dukung lahan. Semakin meningkatnya jumlah penduduk maka kebutuhan pangan akan semakin meningkat. Untuk mendukung ketersediaan pangan di masa yang akan datang salah satu alternatif yang tepat adalah dengan memanfaatkan lahan pekarangan. Menurut Anonim (2009), lahan pekarangan dapat diartikan sebagai tanah sekitar perumahan, kebanyakan berpagar keliling dan biasanya ditanami tanaman padat dengan beraneka macam tanaman semusim maupun tanaman tahunan untuk keperluan sehari-hari dan untuk diperdagangkan. Lahan pekarangan menjadi salah satu sumber pangan keluarga yang relatif murah dan mudah dimanfaatkan.
Meskipun pemanfaatan lahan pekarangan hanya di lakukan sebagai pekerjaan sambilan, namun pekarangan dapat berperan penting dalam mendukung kehidupan sosial ekonomi keluarga, khususnya keluarga petani. Pekarangan sering disebut lumbung hidup, warung hidup dan apotik hidup, dapat disebut lumbung hidup karena sewaktu-waktu kebutuhan pangan pokok seperti beras, jagung, umbi-umbian, dan sebagainya tersedia di pekarangan. Disebut juga warung hidup karena dalam pekarangan terdapat berbagai komoditas sayuran yang berguna untuk memenuhi kebutuhan konsumsi keluarga dimana sebagian rumah tangga harus membelinya dengan uang tunai. Sebagai apotik hidup karena lahan pekarangan ditanami berbagai jenis tanaman obat-obatan yang sangat bermanfaat dalam menyembuhkan penyakit secara tradisional.

Desa Para-Lele Kecamatan Tatoareng Kabupaten Kepulauan Sangihe merupakan salah satu desa yang terdapat di Kecamatan Tatoareng. Sumber mata pencaharian utama masyarakat desa Para-Lele adalah nelayan. Ibu-ibu rumah tangga di Desa Para Lele memiliki waktu luang sekitar 5-8 jam pada siang hari untuk mengembangkan kegiatan budidaya sayuran dan rempah di lahan pekarangan untuk memenuhi kebutuhan sehari-hari. Keadaan atau kondisi pulau ini kecil, bahan pangan seperti rempah-rempah dan sayur-sayuran lebih banyak di pasok dari luar pulau, akses sumber pangan jauh dan tidak setiap hari tersedia dan diperoleh, sehingga harga bahan pangan khususnya sayuran dan rempah menjadi mahal dibandingkan dengan wilayah lain di Kabupaten Kepulauan Sangihe. Masalah atau tantangan lain adalah budidaya pertanian khususnya kebutuhan pangan seperti sayuran dan rempah di pulau kecil yang ukuran lahannya yang terbatas, tanah yang kurang subur, untuk mendapatkan air yang tergolong sulit, sehingga keluarga megembangkan budidaya bahan pangan seperti sayuran dan rempah terbatas, namun pekarangan rumah masih luas untuk potensi mengembangkan bahan pangan khususnya sayuran dan rempah 
dengan luas pekarangan sekitar $100-120 \mathrm{~m}^{2}$. Masyarakat juga memiliki waktu luang untuk mengembangkan kegiatan budidaya sayuran dan rempah di pekarangannya di luar mata pencaharian sebagai nelayan.

Dengan perolehan kebutuhan pangan sehari-hari yang tergolong sulit, maka sebagian keluarga petani di Desa Para-Lele telah memanfaatkan lahan pekarangan dengan membudidayakan tanaman pangan khususnya sayuran dan rempah seperti cabai, tomat, kunyit, bawang merah, kemangi, singkong, pepaya, labu kuning, seledri, bayam, sere, mentimun, pare, jeruk dan berbagai jenis tanaman pangan lainnya. Namun hasil dari pekarangan belum bisa mencukupi sepenuhnya kebutuhan pangan keluarga petani itu sendiri khususnya sayuran dan rempah. Karena keluarga petani yang menanam sayuran dan rempah terkadang hasil tanamannya di pekarangan di bagi hasilnya dengan keluarga tetangga. Penelitian ini hendak mengembangkan budidaya bahan pangan keluarga petani khususnya sayuran dan rempah dengan memanfaatkan lahan pekarangan yang dimiliki oleh keluarga petani di Desa Para-Lele, Kecamatan Tatoareng, Kabupaten Kepulauan Sangihe.

\section{Rumusan Masalah}

Berdasarkan latar belakang yang telah diuraikan maka yang menjadi rumusan masalah dalam penelitian ini yaitu:

1. Berapa besar luas lahan pekarangan keluarga petani untuk budidaya sayuran dan rempah di Desa Para-Lele?

2. Berapa besar biaya dan belanja kebutuhan bahan pangan keluarga petani khususnya sayuran dan rempah di Desa Para-Lele?

\section{Tujuan Penelitian}

Berdasarkan rumusan masalah yang telah diuraikan diatas maka yang menjadi tujuan dalam penelitian ini yaitu:

1. Untuk mengindentifikasi luas lahan pekarangan keluarga petani untuk budidaya sayuran dan rempah di Desa Para-Lele.
2. Untuk mengindentifikasi biaya kebutuhan dan belanja bahan pangan keluarga petani khususnya sayuran dan rempah di Desa Para-Lele.

\section{Manfaat Penelitian}

Berdasarkan rumusan masalah dan tujuan yang telah diuraikan diatas maka yang menjadi manfaat dalam penelitian ini yaitu:

1. Bagi Masyarakat: Dapat berkembangnya kegiatan masyarakat dalam budidaya pertanian di lahan pekarangan guna memenuhi kebutuhan pangan dan sekaligus mengurangi biaya belanja konsumsi.

2. Bagi pemerintah: Bagi Pemerintah Desa Para Lele (khususnya) dan Pemerintah Desa lainnya, penelitian ini dapat dijadikan bahan pertimbangan dalam merumuskan kebijakan pengembangan pertanian, baik itu pertanian diperkotaan maupun pertanian dipedesaan.

\section{METODOLOGI PENELITIAN}

\section{Waktu Dan Tempat Penelitian}

Penelitian ini dilaksanakan selama tiga bulan yaitu dari bulan September 2017 sampai Januari tahun 2018 mulai dari persiapan sampai penyusunan laporan penelitian. Tempat penelitian adalah di Desa Para-Lele, Kecamatan Tatoareng, Kabupaten Sangihe.

\section{Metode Pengumpulan Data}

Data yang di gunakan dalam penelitian ini adalah data primer dan sekunder. Data primer di peroleh dari responden melalui survey, dokumentasi, wawancara dengan menggunakan daftar pertanyaan yang sudah disiapkan terlebih dahulu. Sedangkan data sekunder di peroleh dari jurnal/skripsi, internet dan Kantor Desa Para-Lele. 


\section{TeknikPengambilan Sampel}

Jumlah sampel yang digunakan dalam penelitian ini sebanyak 30 keluarga petani dengan ketentuan keluarga petani yang menanam sayuran dan rempah di pekarangan sebanyak 15 responden dan keluarga petani yang tidak menanam sayuran dan rempah di pekarangan sebanyak 15 responden.

\section{Konsep Pengukuran Variabel}

1. Indentitas Responden

a. Umur yaitu usia sejak responden di lahirkan sampai saat menjadi responden dalam penelitian (tahun).

b. Tingkat pendidikan formal yaitu lamanya responden duduk dibangku sekolah formal: SD, SMP, SMA, Perguruan tinggi (tahun).

c. Jumlah tanggungan keluarga yaitu menunjukan jumlah anggota keluarga dalam rumah tangga responden (orang).

2. Lahan pekarangan pada penelitian ini adalah luas lahan pekarangan $\left(\mathrm{m}^{2}\right)$ yang dimiliki oleh setiap keluarga petani di Desa Para-Lele.

3. Biaya kebutuhan pangan pada penelitian ini yaitu besarnya biaya yang di keluarkan oleh setiap keluarga petani untuk konsumsi bahan pangan khususnya sayuran dan rempah,antara lain:
a. Konsumsi sayuran (Rp) per/ bulan
b. Konsumsi rempah (Rp) per/ bulan

\section{Metode Analisis Data}

Data yang dikumpulkan pada penelitian ini akan diolah dengan menggunakan analisis secara deskriptif. Menurut Sugiyono 2010, yaitu metode yang bertujuan untuk melukiskan atau mengggambarkan keadaan di lapangan secara sistematis dengan fakta-fakta dengan interpretasi yang tepat, serta bukan hanya untuk mencari pemahaman observasi. Kemudian Analisis Data ini diolah/disajikan dalam bentuk tulisan dan Tabel.

\section{HASIL DAN PEMBAHASAN}

\section{Deskripsi Lokasi Penelitian}

\section{Keadaan Geografis Lokasi Penelitian}

Desa Para-Lele merupakan salah satu desa yang terdapat di Kecamatan Tatoareng, Kabupaten Kepulauan Sangihe. Dimana Desa Para-lele dulunya masih tergabung dengan Desa Salengkere dengan Desa Apeng lawo menjadi satu Kepala Desa, namun dengan meningkatnya jumlah di desa para-lele sehingga Desa Para-lele ini berdiri sendiri menjadi satu desa. Kondisi desa para-lele adalah desa kecil yang terdapat dipulau kecil pula. Desa Para-lele terletak pada ketinggian $\pm 5-80 \mathrm{~m}$ dari permukaan laut, dengan suhu udara $25-31^{\circ} \mathrm{C}$ dan luas wilayah desa paralele adalah \pm 2 ha dimana terdapat dataran rendah dan pegunungan. Selain itu desa Paralele diapit oleh tiga pulau yaitu sebelah barat ada pulau nitu, sebelah timur ada Pulau Salengkere dan Pulau Apeng Lawo. Meskipun desa ini kecil dan terdapat di pulau pula, namun memiliki keunikan tersendiri dimana Desa Para-Lele ini di kelilingi oleh pasir putih dengan ikan yang berlimpah. Selain itu Desa-Para Lele ini diapit oleh dua gunung berapi yaitu bagian selatan ada gunung Karangetan tepatnya di Siau dan sebelah barat ada gunung bawa laut tepatnya di Mahangetang. Penggunaan lahan di Desa ParaLele secara umum adalah perkebunan kelapa dan untuk di pekarangan adalah jenis tanaman rempah-rempah dan sayuran seperti cabai, tomat, kunyit, bawang merah, kemangi, singkong, pepaya, labu kuning, sere, jahe, lingkuas dan jenis pohon lainnya seperti kelapa dan mangga.

\section{Keadaan Penduduk Lokasi Penelitian}

Berdasarkan data sensus penduduk 2010, Jumlah penduduk di Desa Para Lele adalah 741 jiwa dengan jumlah laki-laki sebanyak 351 jiwa dan jumlah perempuan sebanyak 390 jiwa. Penduduk Desa Para Lele menurut jenis kelamin dapat dilihat pada Tabel 1. 
Tabel 1. Jumlah dan presentase Menurut Jenis Kelamin Tahun 2016

\begin{tabular}{lrr}
\hline \multicolumn{1}{c}{$\begin{array}{c}\text { Jenis } \\
\text { kelamin }\end{array}$} & \multicolumn{1}{c}{$\begin{array}{c}\text { Jumlah } \\
\text { penduduk } \\
\text { (jiwa) }\end{array}$} & $\begin{array}{c}\text { Persentase } \\
(\boldsymbol{\%})\end{array}$ \\
\hline Laki -Laki & 493 & 50,92 \\
Perempuan & 475 & 49,07 \\
\hline Jumlah & 968 & 100 \\
\hline
\end{tabular}

Sumber data: Kontor Desa Para-Lele, 2016

Berdasarkan Pada Tabel 1, menunjukan jumlah dan presentase penduduk di Desa Para-Lele pada Tahun 2016. Berdasarkan data sensus kependudukan Desa Para-Lele Tahun 2016, dapat diketahui bahwa jumlah penduduk laki - laki lebih banyak di bandingkan dengan jumlah penduduk perempuan dimana jumlah laki - laki sebanyak 493 orang dengan persentase 50,92 \% sedangkan jumlah perempuan sebanyak 475 orang dengan persentase 49,07\%. Perbedaan presentase antara jumlah penduduk laki-laki dengan jumlah penduduk perempuan yaitu sebanyak $1,85 \%$. Sebagian besar sumber pendapatan masyarakat Desa Para-Lele adalah nelayan dan perkebunan kelapa. Ketersediaan pangan masyarakat Desa Para-Lele yang masih tergolong sulit untuk memperoleh kebutuhan pangan khususnya kebutuhan pangan, sandang dan papan, dimana transportasi untuk mengangkut kebutuhan pangan ke Desa ParaLele harus menyeberangi lautan, sehingga menyebabkan biaya kebutuhan pangan jadi mahal dibandingkan dengan daerah lain.

\section{Karakteristik RespondenUmur}

Umur merupakan faktor yang dapat mempengaruhi petani terhadap penyerapan dan pengambilan keputusan dalam menerapkan teknologi baru maupun inovasi baru pada usahataninya dalam penelitian ini adalah usahatani di lahan pekarangan. Umur merupakan salah satu indikator produktif atau tidaknya pengusaha dalam mengelola usahanya. Berdasarkan hasil penelitian mengenai umur responden dapa dilihat pada Tabel 2.

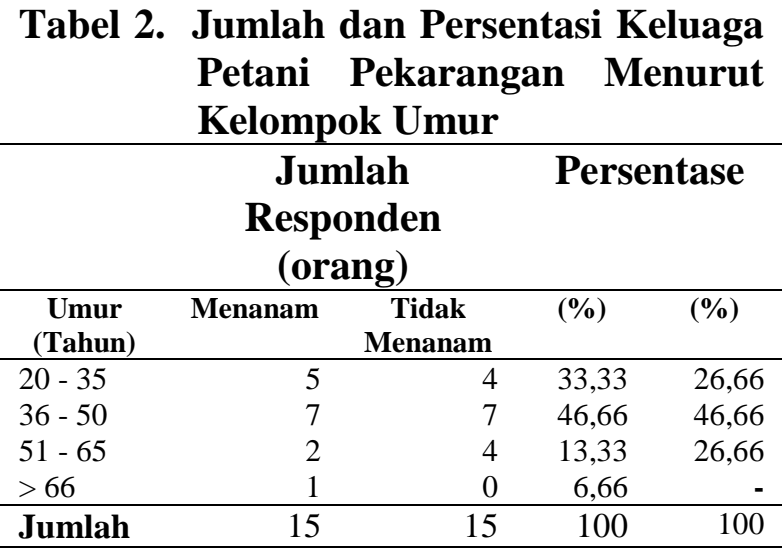

Sumber data: Diolah dari data primer, 2017

\section{Pada Tabel 2 dapat dilihat bahwa} sebagian besar keluarga petani pada rentang kelompok umur 36-50 tahun memiliki jumlah responden terbanyak baik keluarga petani yang menanam maupun yang tidak menanam dengan jumlah reponden masing-masing dengan jumlah 7 responden dengan persentase $46,66 \%$. dan diikuti oleh rentang kelompok umur 20 sampai 35 tahun dengan keluarga petani yang menanam sebanyak 5 responden dengan persentase 33,33\% dan yang tidak dengan jumlah responden sebanyak 4 orang dengan persentase 26,66 $\%$. dan pada rentang kelompok umur $>66$ tahun memiliki jumlah responden paling sedikit dengan yang menanam sebanyak 1 orang dengan persentase $6,66 \%$. Sedangkan yang tidak menanam tidak ada responden. Berdasarkan hasil perhitungan rata-rata umur kelurga petani baik yang menanam maupun yang tidak menanam berada pada umur ratarata 81 tahun. Hal ini berarti masih tergolong umur yang masih produktif. Dengan kondisi umur petani yang masih tergolong produktif ini maka diharapkan kelurga petani memiliki kemampuan fisik yang kuat sehingga memberikan sumbangan tenaga kerja yang lebih besar terhadap usahataninya di lahan pekarangan, dengan demikian diharapkan nantinya dapat meningkatkan produksi tanaman khususnya sayuran dan rempah dan secara otomatis akan dapat meningkatkan pendapatan keluarga petani. 


\section{Tingkat Pendidikan}

Pendidikan mempengaruhi petani dalam mengelola usahatani lahan pekarangannya, karena tingkat pendidikan dan pengetahuan seseorang akan membantu untuk berpikir dan penuh pertimbangan. Rendahnya tingkat pendidikan formal yang ada pada petani dapat diatasi dengan pendidikan non formal yaitu meningkatkan pembinaan dan penyuluhan karena penyuluhan adalah pendidikan non formal yang dapat diterapkan dan diikuti petani dan keluarganya. Berperan dalam memberikan pengetahuan, keterampilan, pembangunan pola pikir, perilaku dalam berusahatani. Pada penelitian ini yang diambil sebagai patokan adalah pendidikan formal yang pernah dilalui oleh responden untuk mengukur tingkat pengetahuannya. Adapun data mengenai tingkat pendidikan dapa dilihat pada Tabel 3 .

Tabel 3. Jumlah Dan Persentase Keluarga Petani Pekarangan Menurut Tingkat Pendidikan

\begin{tabular}{lcrrr}
\hline & \multicolumn{2}{c}{ Jumlah Responden (orang) } & \multicolumn{3}{c}{ Persentase } \\
\hline $\begin{array}{c}\text { Tingkat } \\
\text { Pendidikan }\end{array}$ & Menanam & $\begin{array}{c}\text { Tidak } \\
\text { Menanam }\end{array}$ & $\mathbf{( \% )}$ & $(\boldsymbol{\%})$ \\
\hline SD & 5 & 5 & 33,33 & 33,33 \\
SMP & 9 & 9 & 60,00 & 60,00 \\
SMA & 1 & 1 & 6,66 & 6,66 \\
\hline Jumlah & 15 & 15 & 100 & 100 \\
\hline
\end{tabular}

Sumber data: diolah dari data primer, 2017

Berdasarkan pada Tabel 3, dapat diketahui tingkat pendidikan baik keluarga petani yang menanam maupun keluarga petani yang tidak menanam. hasil penelitian menunjukan bahwa tingkat pendidikan paling tinggi oleh keluarga petani yang menanam yaitu berada pada tingkat SMP dengan jumlah responden 9 orang dengan persentase 60,00 $\%$. Tingkat pendidikan paling rendah pada keluarga petani yang menanam berada pada tingkat pendidikan SMA dengan jumlah responden 1 orang dengan persentase $6,66 \%$. Sedangkan tingkat pendidikan keluarga petani yang tidak menanam jumlah responden paling banyak yaitu berada pada tingkat pendidikan SMP dengan jumlah responden 9 orang dengan persentase $60,00 \%$. Tingkat pendidikan paling rendah pada kelurga petani yang tidak menanam berada pada tingkat pendidikan SMA dengan jumlah responden 1 orang dengan persentase $6,66 \%$. Hal ini dapat diartikan bahwa tingkat pendidikan responden yang relatif rendah namun dapat diimbangi oleh pendidikan di non formal. Menurut Ranti (2009), bahwa semakin tinggi tingkat pendidikan seseorang, maka akan cepat tanggap terhadap perkembangan teknologi dan kemampuan seseorang. Sedangkan data mengenai jumlah anggota keluarga responden.

\section{Jumlah Anggota Keluarga}

Jumlah tanggungan keluarga merupakan jumlah seluruh anggota keluarga yang masih sekolah dan bukan atau tidak bekerja, dimana segala kebutuhan hidupnya ditanggung oleh kepala keluarga/kepala rumah tangga yang akan berpengaruh pada aktivitas dan cara pengambilan keputusan serta kemampuan petani dalam mengelola usahatani lahan pekarangan. Jumlah anggota keluarga erat kaitanya dengan pendapatan. Jumlah anggota keluarga yang berada pada usia produktif merupakan sumber tenaga kerja yang akan meningkatkan pendapatan usahatani karena dapat aktif pada usahataninya. Apabila seseorang tidak berusia produktif maka dianggap menjadi beban bagi kepala keluarga. Anggota keluarga petani terdiri dari istri, anak, adik, orangtua, dan anggota keluarga lainnya, dimana kebutuhan sehari-hari ditanggung oleh rumah tangga petani yang bersangkutan.Adapun mengenai jumlah anggota kelurga dapat dilihat pada Tabel 4.

Tabel 4. Jumlah Dan Persentase Responden Menurut

\begin{tabular}{lcrrr}
\multicolumn{5}{c}{ Jumlah Anggota Keluarga } \\
\hline \multicolumn{5}{c}{$\begin{array}{c}\text { Jumlah Responden } \\
\text { (orang) }\end{array}$} \\
\hline $\begin{array}{c}\text { Jumlah } \\
\text { Tanggungan } \\
\text { (orang) }\end{array}$ & Menanam & $\begin{array}{c}\text { Tidak } \\
\text { Menanam }\end{array}$ & $\mathbf{( \% )}$ & $\mathbf{( \% )}$ \\
\hline $1-3$ & & & & \\
$4-6$ & 5 & 6 & 33,33 & 33,33 \\
$7-9$ & 9 & 7 & 60,00 & 46,66 \\
\hline Jumlah & 2 & 2 & 13,33 & 13,33 \\
\hline Sumber data: diolah dari data primer, 2017 & & \\
\end{tabular}


Berdasarkan pada Tabel 4, dapat diketahui jumlah tanggungan anggota keluarga baik keluarga petani yang menanam maupun yang tidak menanam semua mempunyai anggota keluarga. Jumlah tanggungan anggota keluarga yang menanam, jumlah responden paling banyak berada pada jumlah tanggungan antara $4-6$ anggota keluarga dengan jumlah responden 9 orang dengan persentase $60,00 \%$. Hasil perhitungan jumlah tanggungan anggota keluarga petani rata-rata 8 jumlah tanggungan anggota keluarga. Jumlah tanggungan anggota Keluarga yang tidak menanam jumlah responden terbanyak berada pada jumlah $4-6$ dengan jumlah responden 7 orang dengan persentase $46,66 \%$. Hasil perhitungan rata-rata jumlah tanggungan anggota keluarga adalah 7 orang. Penelitian ini dapat disimpulkan bahwa rata-rata jumlah tanggungan angggota keluarga yang menanam lebih banyak dibandingkan dengan keluarga petani yang tidak menanam yaitu 8 jumlah tanggungan keluarga petani yang menanam dengan 7 jumlah tanggungan keluarga yang tidak menanam.

\section{Luas Lahan Pekarangan}

Luas lahan mempengaruhi besar kecilnya produksi hasil tani. Semakin luas lahan pertanian maka semakin efisien lahan tersebut. Namun besarnya luas lahan tidak selalu menjamin keberhasilan usahataninya karena ada faktor-faktor penghambat seperti iklim, hama dan penyakit dan sebagainya yang dapat menghambat pertumbuhan tanaman. adapun data mengenai luas lahan pekarangan yang dimiliki oleh keluarga petani di Desa Paralele dapat dilihat pada Tabel 5.

Tabel 5. Jumlah dan Presentase Responden Menurut Kelompok Luas Lahan Pekarangan

\begin{tabular}{ccrrr}
\multicolumn{5}{c}{ Kelompok Luas Lahan Pekarangan } \\
\hline \multicolumn{5}{c}{$\begin{array}{c}\text { Jumlah Responden } \\
\text { (orang) }\end{array}$} \\
\hline $\begin{array}{c}\text { Luas } \\
\text { pekarangan } \\
\left(\mathbf{m}^{2}\right)\end{array}$ & Menanam & $\begin{array}{c}\text { Tidak } \\
\text { Menanam }\end{array}$ & $\mathbf{( \% )}$ & $(\boldsymbol{\%})$ \\
\hline $100-120$ & & 4 & 40,00 & 26,66 \\
$121-140$ & 3 & 7 & 20,00 & 46,66 \\
$141-160$ & 3 & 3 & 26,66 & 20,00 \\
$>161$ & 4 & 1 & 13,33 & 6,66 \\
\hline Jumlah & 2 & 15 & 100 & 100 \\
\hline Sumber data : diolah dari data primer, 2017
\end{tabular}

Berdasarkan Tabel 5, dapat diketahui luas lahan pekarangan yang dimiliki oleh keluarga petani baik keluarga petani yang menanam maupun yang tidak menanam di pekarangan. Data menunjukan bahwa luas lahan pekarangan yang di miliki oleh keluarga petani masih cukup luas untuk budidaya sayuran dan rempah. Keluarga petani yang menanam jumlah responden paling banyak berada pada luasan antara $100 \mathrm{~m}^{2}-120 \mathrm{~m}^{2}$ sebanyak 6 orang dengan persentase $40,00 \%$. Berdasarkan hasil perhitungan menunjukan rata-rata luas pekarangan keluarga petani yang menanam yaitu rata-rata $128,86 \mathrm{~m}^{2}$. Keluarga petani yang tidak menanam di pekarangan jumlah responden paling banyak berada pada luasan antara $121-140 \mathrm{~m}^{2}$ dengan jumlah responden sebanyak 7 orang dengan persentase 46,66 \%. Berdasarkan Hasil perhitungan di peroleh rata- rata luas pekarangan oleh keluarga petani yang tidak menanam rata-rata yaitu $127,53 \mathrm{~m}^{2}$. Luas pekarangan keluarga petani, baik keluarga petani yang menanam maupun yang tidak menanam memiliki perbedaan dimana keluarga petani yang menanam lebih besar dibandingkan dengan keluarga petani yang tidak menanam.

\section{Biaya Kebutuhan Pangan Sayuran Dan Rempah}

Pengeluaran petani adalah jumlah seluruh pengeluaran uang oleh petani untuk berbagai kebutuhan keluarga selama satu tahun dalam rupiah. Pengeluaran keluarga petani dalam penelitian ini yaitu pengeluaran untuk kebutuhan keluarga sehari-hari khususnya sayuran dan rempah dalam satu bulan. Dimana penelitian ini melihat perbandingan antara keluarga petani yang menanam di pekarangan dan yang keluarga petani yang tidak menanam di lahan pekarangan. Untuk melihat biaya kebutuhan pangan sayuran dan rempah oleh keluarga petani baik yang menanam sayuran dan rempah maupun yang tidak menanam sayuran dan rempah dalam satu bulan, dapat di lihat pada Tabel 6. 
Tabel 6. Jumlah Responden Menurut Besarnya Biaya Konsumsi Sayuran Dalam Satu Bulan

\begin{tabular}{lrrrr}
\hline & \multicolumn{1}{c}{$\begin{array}{c}\text { Jumlah } \\
\text { Responden } \\
\text { (orang) }\end{array}$} & \multicolumn{2}{c}{ Persentase } \\
\hline Pengeluaran (Rp) & Menanam & $\begin{array}{c}\text { Tidak } \\
\text { Menanam }\end{array}$ & $(\boldsymbol{\%})$ & $(\boldsymbol{\%})$ \\
\hline $60.000-329.000$ & 2 & 1 & 13,33 & 6,66 \\
$330.000-599.000$ & 4 & 2 & 26,66 & 13,33 \\
$560.000-829.000$ & 1 & 3 & 6,66 & 20,00 \\
$>830.000$ & 8 & 9 & 53,33 & 60,00 \\
\hline Jumlah & 15 & 15 & 100 & 100 \\
\hline Sumber data : diolah dari data primer, 2017 & &
\end{tabular}

Berdasarkan pada Tabel 6, dapat diketahui besarnya biaya kebutuhan pangan baik keluarga petani yang menanam maupun yang tidak menanam khususnya sayuran dalam satu bulan. Data menunjukan bahwa Jumlah responden yang menanam paling banyak berada pada biaya diatas $>\mathrm{Rp}$ 830.000 dengan jumlah responden 8 orang dengan persentase 53,33\%. Berdasarkan Hasil perhitungan di peroleh biaya rata-rata kebutuhan sayuran keluarga petani yang menanam yaitu biaya rata-rata sebesar $\mathrm{Rp}$ 689.000 per/bulan. Sedangkan keluarga petani yang tidak menanam jumlah biaya kebutuhan yang di keluarkan diatas Rp.830.000 dengan jumlah responden 9 orang dengan persentase $53,33 \%$. Berdasarkan Hasil perhitungan di peroleh rata-rata kebutuhan sayuran oleh keluarga petani yang tidak menanam adalah rata-rata sebesar Rp 998.000 per/bulan. Berdasarkan hasil perhitungan rata-rata kebutuhan pangan sayuran baik keluarga petani yang menanam maupun yang tidak menanam mempunyai perbedaan. Dimana biaya kebutuhan sayuran yang menanam lebih kecil di bandingkan dengan keluarga petani yang tidak menanam sayuran. Karena keluarga petani yang menanam kebutuhan pangan sayuran sebagian telah tersedia di lahan pekarangan sedangkan keluarga petani yang tidak menanam harus mengeluarkan biaya untuk memperoleh kebutuhan sayuran. Adapun jumlah responden menurut besarnya biaya kebutuhan rempah dalam satu bulan, dapat dilihat pada Tabel 7.
Berdasarkan pada Tabel 8, dapat diketahui jumlah responden menurut besarnya biaya kebutuhan rempah, baik keluarga petani yang menanam maupun yang tidak menanam selama satu bulan. Data menunjukan bahwa keluarga petani yang menanam jumlah responden paling banyak berada pada biaya antara 289.000 - 576.000 dengan jumlah responden 8 orang dengan persentase $53,33 \%$. Berdasarkan Hasil perhitungan di peroleh rata-rata kebutuhan rempah keluarga petani yang menanam yaitu rata-rata Rp.629.000 per/bulan. Sedangkan keluarga petani yang tidak menanam jumlah responden terbanyak pada biaya diatas Rp. 865.000 dengan jumlah responden 7 orang dengan persentase 46,66 $\%$. Berdasarkan hasil perhitungan diperoleh rata-rata kebutuhan rempah oleh keluarga petani yang tidak menanam yaitu Rp.1.076.000 per/bulan. Biaya kebutuhan keluarga petani khusussnya rempah baik keluarga petani yang menanam maupun yang tidak menanam mempunyai perbedaan dimana keluarga petani yang menanam mengeluarkan biaya lebih kecil di bandingkan keluarga petani yang tidak menanam. Hal ini dapat di artikan bahwa keluarga petani yang menanam sebagian besar kebutuhan rempah telah tersedia di pekarangan. Sedangkan keluarga petani yang tidak menanam harus mengeluarkan biaya untuk memperoleh kebutuhan pangan seperti rempah-rempah. Adapun alasan keluarga petani menanam sayuran dan rempah di lahan pekarangannya, dapat dilihat pada Tabel 8.

Tabel 8. Jumlah Responden Menurut Alasan Keluarga Petani Menanam Sayuran Dan Rempah di Pekarangan

\begin{tabular}{lcc}
\hline Alasan & $\begin{array}{c}\text { Jumlah } \\
\text { Responden } \\
\text { (Orang) }\end{array}$ & $\begin{array}{c}\text { Persentase } \\
(\boldsymbol{\%})\end{array}$ \\
\hline $\begin{array}{l}\text { Agar lahan tersebut } \\
\text { tidak sia - sia }\end{array}$ & 3 & 20,00 \\
$\begin{array}{l}\text { Untuk memenuhi } \\
\text { kebutuhan sehari-hari } \\
\begin{array}{l}\text { Mengisi waktu yang } \\
\text { kosong }\end{array}\end{array}$ & 10 & 66,66 \\
\hline Jumlah & 2 & 13,33 \\
\hline
\end{tabular}

Sumber data: diolah dari data primer, 2017 
Berdasarkan Tabel 8, dapat diketahui beberapa alasan keluarga petani memanfaatkan lahan pekarangan yang dimiliki oleh keluarga petani yang menanam sayuran dan rempah, alasan pertama yaitu agar lahan tidak sia - sia sebanyak 3 responden dengan presentase 20,00 \%, sedangkan alasan kedua yaitu untuk memenuhi kebutuhan sehari-hari sebanyak 10 responden dengan presentase $66,66 \%$, alasan ketiga yaitu mengisi waktu yang kosong sebanyak 2 responden dengan presentase $13,33 \%$.

Hasil penelitian ini menunjukan keluarga petani bahwa karakteristik dari keluarga petani memanfaatkan lahan pekarangan pada dasarnya hanya semata ditujukan untuk pemenuhan kebutuhan pangan keluarga sehari-hari khususnya lauk pauk, dan tidak di komersialkan karena semua hasil dari pekarangan sepenuhnya untuk memenuhi kebutuhan keluarganya. Untuk lebih jelasnya, adapun alasan-alasan keluarga petani tidak menanam sayuran dan rempah di lahan pekarangan, dapat dilihat pada Tabel 9.

Tabel 9. Alasan Keluarga Petani Tidak Menanam

\begin{tabular}{lcr}
\multicolumn{3}{c}{ Sayuran dan Rempah Pekarangan } \\
\hline Alasan & $\begin{array}{c}\text { Jumlah } \\
\text { Responden } \\
\text { (Orang) }\end{array}$ & $\begin{array}{c}\text { Persentase } \\
(\%)\end{array}$ \\
\hline $\begin{array}{l}\text { Tanah yang tidak } \\
\text { subur }\end{array}$ & 4 & 26,66 \\
$\begin{array}{l}\text { Tidak mempunyai } \\
\text { benih/ bibit }\end{array}$ & 2 & 13,33 \\
$\begin{array}{l}\text { Tanaman mudah } \\
\text { terkena air laut } \\
\text { Tidak ada pupuk }\end{array}$ & 7 & 46,66 \\
\hline Jumlah & 2 & 13,33 \\
\hline Sumber : Diolah Data Primer, 2017 & 15 & 100 \\
\hline
\end{tabular}

Sumber : Diolah Data Primer, 2017

Berdasarkan pada Tabel 9, dapat diketahui bahwa ada beberapa alasan keluarga petani tidak menanam tanaman di lahan pekarangan. Alasan-alasan tersebut dapat dilihat pada tabel di atas dimana alasan tanah yang tidak subur sebanyak 4 responden dengan persentase $26,66 \%$, alasan tidak mempunyai benih/bibit sebanyak 2 responden dengan persentase $13,33 \%$, alasan tanaman mudah terkena air laut sebanyak 7 responden dengan persentase $46,66 \%$ dan alasan terakhir yaitu tidak ada pupuk berjumlah 2 responden dengan persentase $13,33 \%$. Hal ini dibuktikan oleh sebagian besar jumlah responden yang memberikan alasan yaitu bawha keluarga petani tidak menanam tanaman di pekarangan karena jenis tanaman yang ditanam mudah terkena air laut, tanaman yang di tanam di pekarangan sebelum pasca panan mudah terkena air laut sehingga mengakibatkan tanaman cepat mati. Keluarga petani telah berusaha berulang-ulang menanam tanaman dipekarangannya,namun tidak memberi hasil yang baik. Secara umum adapun bentukbentuk pemanfaatan lahan pekarangan yang dikembangkan oleh keluarga petani yang menanam sayuran dan rempah di pekarangannya dapat dilihat pada Tabel 10.

Tabel 10. Bentuk-Bentuk Pemanfaatan Lahan Pekarangan yang di Usahakan oleh Keluarga Petani

\begin{tabular}{lrr}
\hline Klasifikasi & $\begin{array}{c}\text { Jumlah Responden } \\
\text { (Orang) }\end{array}$ & Persentase (\%) \\
\hline Pertanian & 13 & 43,33 \\
Peternakan & 10 & 33,33 \\
Bentuk Usaha & 7 & 23,33 \\
Lainnya & & \\
\hline Jumlah & 30 & $100 \%$ \\
\hline Sumber Data: Diolah Data Primer, 2017
\end{tabular}

Berdasarkan Pada Tabel 10, dapat dilihat bahwa sebagian besar dari keluarga petani memanfaatkan lahan pekarangan yang di miliki adalah untuk pertanian. Dimana pertanian sebanyak 13 responden dengan persentase 43,33\%. Pertanian seperti cabai, tomat, kunyit, jahe, jeruk, pepaya, kemangi, labu kuning, sere, lengkuas, pandan, terong, mentimun, ubi jalar, ubi kayu dan berbagai jenis tanaman pangan lainnnya. Dan untuk peternakan seperti peternakan ayam dan babi, sebanyak 10 responden dengan persentase $33,33 \%$ dan bentuk usaha lainya seperti konter pulsa, jualan sembako, kios sebanyak 7 responden dengan persentase $23,33 \%$. Hal ini menujukan bahwa meskipun kelurga petani tidak menanam tanaman dilahan pekarangan akan tetapi keluarga petani mempunyai usaha lain diluar pertanian dan perkebunan yaitu 
peternakan dan bentuk usaha lainnya. Untuk pola budidaya sayuran dan rempah oleh keluarga petani yang menanam sayuran dan rempah dipekarangan sebagian besar menanam langsung di tanah (konvesional) dan sebagian kecil menanam menggunakan polybag dan ember. Adapun jenis tanaman keluarga petani pada lahan pekarangan di Desa Para- Lele, dapat dilihat pada Tabel 11.

Tabel 11. Jenis Tanaman yang Ditanam di Pekarangan oleh Keluarga Petani di Desa Para-Lele

\begin{tabular}{|c|c|c|}
\hline \multicolumn{3}{|c|}{$\begin{array}{l}\text { Jenis Tanaman yang Ditanam di Pekarangan oleh } \\
\text { Keluarga Petani }\end{array}$} \\
\hline Sayuran & Rempah & Pohon \\
\hline Kangkung & Cabai & Pisang \\
\hline Terong & Tomat & Mangga \\
\hline Mentimun & Sere & Nangka \\
\hline Bayam & Kunyit & Jambu Mente \\
\hline Labu Kuning & Bawang Daun & Sirsak \\
\hline Kacang & Kemangi & Kemiri \\
\hline \multicolumn{3}{|l|}{ Panjang } \\
\hline Gedi & Jahe & Belimbing \\
\hline $\begin{array}{l}\text { Katimum } \\
\text { jepang }\end{array}$ & Lengkuas & Pepaya \\
\hline Paria & Seledri & Kelapa \\
\hline Bunga pepaya & Daun jeruk & Jeruk \\
\hline
\end{tabular}

Sumber Data: diolah dari data primer, 2017

Berdasarkan pada Tabel 11, dapat diketahui jenis-jenis tanaman yang di budidayakan oleh keluarga petani dilahan pekarangan. Untuk jenis-jenis sayuran yaitu, kangkung, terong, mentimun, bayam, labu kuning, kacang panjang, katimun jepang, dan paria dan untuk jenis-jenis rempah yaitu cabai, tomat, sere, kunyit, bawang daun, kemangi, jahe, lengkuas, seledri, daun lemon dan yang terakhir jenis-jenis pohon yaitu pisang, mangga, nangka, jambu mente, sirsak, kemiri, belimbing, pepaya, kelapa, dan yang terakhir pohon jeruk.

\section{KESIMPULAN DAN SARAN}

\section{Kesimpulan}

Berdasarkan hasil pembahasan yang telah diuraikan diatas maka dapat disimpulkan bahwa rata-rata luas pekarangan keluarga yang menanam berada pada luasan rata-rata 128,86 $\mathrm{m}^{2}$. Sedangkan yang tidak menanam berada pada luasan rata-rata $127,53 \mathrm{~m}^{2}$.
Biaya rata-rata kebutuhan sayuran oleh keluarga petani yang menanam untuk sayuran rata-rata $\mathrm{Rp} 689.000$ per/bulan sedangkan biaya untuk kebutuhan rempah rata-rata $\mathrm{Rp} 629.000$ per/bulan. Biaya rata-rata kebutuhan rempah oleh keluarga petani yang tidak menanam untuk sayuran rata-rata Rp 998.000 per/bulan sedangkan biaya untuk kebutuhan rempah rata-rata Rp1.076.000 per/bulan.

\section{Bagi masyarakat: Hendaknya} memanfaatkan lahan pekarangan yan dimiliki dengan sebaik-baiknya meskipun tanah tersebut tidak begitu luas karena dengan memanfaatkan lahan pekarangan, kita akan memperoleh banyak keuntungan seperti kemudahan dalam memenuhi kebutuhan sehari-hari, dapat mengurangi biaya belanja kebutuhan pangan khususnya sayuran dan rempah dalam penelitian.

Bagi Pemerintah: Pemerintah Desa ParaLele (khususnya) dan pemerintah desa lainnya, hendaknya melakukan sosialisasi dan memberikan himbau kepada masyarakat untuk memanfaatkan pekarangan yang dimiliki. Pemerintah disarankan hendaknya mengadakan survei ke desa untuk dapat mengetahui jenis tanaman yang paling sesuai dan yang paling direspon oleh masyarakat desa, sehingga kontribusi pekarangan dapat meningkat.

\section{DAFTAR PUSTAKA}

2013. Minat Petani Dalam Budidaya Sayuran di Lahan Pekarangan.

Anonim. 2009. "Verticultur-cara tanam bertingkat - pemanfaatan lahan pekarangan diperkotaan. http: goelagoel a. Blogspot. Com/2011/03/ verticulturcara-tanam bertingkat.

Arifin, H. S., Kaswanto. 2009. Pemanfaatan Pekarangan Di Pedesaan. Buku Seri II.Biro Perencanaan Sekjen Deptan Bekerjasama Dengan Departemen Arsiktektur Lanskap, Faperta IPB. Bandung. 
Ashari, A., Saptana, S,.\& T. B. 2012. Potensi Dan Prospek Pemanfaatan Lahan Pekarangan Untuk Mendukung Kebutuhan Pangan. In Forum Penelitian Agro Ekonomi. Jawa Timur.

Ashudhori, M. 2017. Optimalisasi Pemanfaatan Pekarangan. Jurnal Ilmiah Universitas Batanghari. Jambi.

Astuti, U. P. 2012. Petunjuk Teknis: Pemanfaatan Lahan Pekarangan di Provinsi Bengkulu. Balai Pengkajian Teknologi Pertanian Bengkulu. Bengkulu.

Badan Litbang Pertanian. 2011. Pedoman Umum Model Kawasan Rumah Pangan Lestari. Badan Penelitian dan Pengembangan Pertanian. Jakarta.

Dinas Pertanian Jatim .2011. Rumah Hijau Dalam Rangka Optimalisasi Pemanfaatan Pekarangan di Provinsi Jawa Timur. Dinas Pertanian Provinsi Jawa Timur. Surabaya.

Ginting. M dan Penny, D. H . 2012. Pekarangan Petani Dan Kemiskinan. Universitas Gadjah Mada. Yayasan Agro Ekono-Mika. Yogyakarta.

Haerudin. 2010. Pemanfaatan Lahan Pekarangan Sebagai Tambahan Pendapatan Ekonomi Masyarakat Di Desa Wanasaba Kecamatan Wanasaba Kabupaten Lombok Timur. Selong.

Hosen, N. 2008. Potensi dan Masalah Pengembangan Lahan Pekarangan Mendukung Penigkatan Produksi Buah-Buahan di Sumatera Barat. Prosiding Seminar Hortikultura. Puslitbang Hortikultura. Medan.
Junaidah, J., P. S. P., \& Budiadi, B. 2017. Komposisi Jenis dan Fungsi Pekarangan (Studi Kasus Desa Giripurwo, Kecamatan Girimulyo, di Yogyakarta). Jurnal Hutan Tropis. Yogyakarta.

Lakitan, B. 2012. Pengembangan Pola Pemanfaatan Lahan Pekarangan Sebagai Sumber Pendapatan dan Gizi Keluarga di Pedesaan Sumatera Selatan. Palembang.

Mardiharini, M, .2011. Model Kawasan Rumah Pangan Lestari dan Pengembanganya ke Seluruh Provinsi di Indonesia. Warta Penelitian dan Pengembangan Pertanian. Badan Penelitian dan Pengembangan Pertanian. Jakarta.

Nainggolan, K. 2008. Ketahanan dan Stabillitas Pasokan, Permintaan, dan Harga Komoditas Pangan. Analisis Kebijakan Pertanian. Pusat Analisis Sosial Ekonomidan Kebijakan Pertanian. Badan Penelitian dan Pengembangan Pertanian.

Novitasari, E . 2011. Studi Budidaya Tanaman Pangan Di Pekarangan Sebagai Sumber Ketahanan Pangan Keluarga (Studi Kasus di Desa Ampel Gading Kecamatan Tirtoyudo Kabupaten Malang). Skripsi Universitas Brawijaya. Malang.

Rahayu, M. 2011. Keanekaragaman Tanaman Pekarangan dan Pemanfaatannnya di Desa Lampeapi, Pulau WawoniSulawesi Tenggara. Jurnal Teknologi Lingkungan. Kendari.

Ranti, D. 2009. Peranan Program Pemberdayaan Pertanian Lembaga Amil Zakat (LAZ) Swadaya Ummah Terhadap Peningkatan Pendapatan Petani di Kelurahan Kulim Kecamatan Tanayan Raya Kota Pekanbaru. Jurusan Sosial Ekonomi Pertanian Fakultas Pertanian UNRI. Pekanbaru. 
Rukmana, I. H. R. 2008. Temuan Apotek Hidup di Pekarangan. Kanisius. Jakarta.

Saleim, H. P. 2011. Kawasan Rumah Pangan Lestari: Sebagai Solusi Pemantapan Ketahanan Pangan. Makalah disampaikan pada Konggres Ilmu Pengetahuan Nasional (KIPNAS). Jakarta.

Saptana, A ., Ashari, \&, T. B . 2012. Dampak Pengembangan Model Kawasan Rumah Pangan Pangan Lestari Terhadap Kesejahateraan Rumah Tangga dan Ekonomi di Pedesaan. Laporan Penelitian. Pusat Sosial Ekonomi dan Kebijakan Pertanian. Badan Penelitian dan Pengembangan Pertanian.

Surabaya.
Sugiyono. 2010. Metode Penelitian Pendekatan Kualitatif Dan Kualitatif. Alfabeta. Jakarta.

Winardi, W. (2014). Profil Pertanian Terpadu Lahan Pekarangan Di Kota Padang: Tinjauan Budidaya Pertanian. Pertanian Tropik1(1). 